\title{
POSTAĆ HOSPODARA MOŁDAWSKIEGO PIOTRA RAREŞA WE WSPOŁCZESNEJ MU KORESPONDENCJI DYPLOMATYCZNEJ
}

\author{
KATARZYNA NIEMCZYK
}

\begin{abstract}
The image of the ruler of Moldova Petru Rares in contemporary foreign sources.
The aim of the article is to refer how the ruler of Moldova - Petru Rareş was described in the contemporary sources, so that we can find the answer for the question how Petru Rares was perceived by the rulers from Europa and Ottoman Empire. There were analyzed various sources that showed the standpoint of the Polish king Sigismund I, sultan Suleyman the Great, Ferdinand Habsburg towards Rareş. Thanks to this analysis it can be said that the rulers from Europa and Ottoman Empire perceived Rareş as a man who was disloyal, unfaithful and they definitely didn't trust him. This opinion had huge influence on the final defeat of Rareş.
\end{abstract}

Streszczenie. Celem artykułu jest omówienie w jaki sposób hospodar mołdawski Piotr Rareş był przedstawiany w źródłach mu współczesnych, tak by móc ocenić, jak postrzegali hospodara władcy Europy i Turcji. Kolejno przeanalizowano źródła ukazujące stanowisko króla polskiego Zygmunta Starego, sułtana Sulejmana Wspaniałego, Ferdynanda Habsburga oraz Wenecjan wobec Piotra Rareşa. Z analizy źródeł wynika, że władcy mu współcześni odnosili się do hospodara z dużą dozą nieufności, podkreślali jego wiarołomność i nielojalność. Taka opinia zaważyła niewątpliwie na ostatecznej klęsce hospodara i braku poparcia którejkolwiek ze stron.

Autor: Katarzyna Niemczyk, Uniwersytet Śląski, ul. Bankowa 12, 40-007 Katowice, Polska, katarzyna.niem czyk@us.edu.pl, ORCID ID: https://orcid.org/0000-0002-9656-3048

Słowa kluczowe: Petru Rareş, Mołdawia, Zygmunt I, Sulejman Wspaniały, Ferdynand Habsburg, Królestwo Polskie

Keywords: Petru Rareş, Moldova, Sigismund I, Suleyman the Great, Ferdinand Habsburg, Kingdom of Poland

Balcanica Posnaniensia. Acta et studia, XXVII, Poznań 2020, Wydawnictwo Wydziału Historii UAM, pp. 5768, ISBN 978-83-66355-54-5, ISSN 0239-4278. Polish text with summaries in English and Polish.

doi.org/10.14746/bp.2020.27.4

Piotr Rareş objął rządy w Mołdawii w roku 1527 jako następca Stefana Młodego (zwanego Ştefăniţă). Podawał się za naturalnego syna Stefana Wielkiego i w swojej polityce próbował naśladować swego znakomitego poprzednika. Jego sytuacja polityczna była jednak dużo trudniejsza wobec rozpadu Węgier, a przede wszystkim uznania przez Jana Zápolyę zwierzchnictwa sułtana Sulejmana. Wobec faktu, że Mołdawia była w pierwszym ćwierćwieczu XVI wieku lennem węgierskim, sułtan począł wówczas uznawać hospodara mołdawskiego za swojego lennika zobowiązanego do pełne- 
go podporządkowania politycznego i opłaty podwyższonego trybutu. Piotr Rareş poszukiwał wyjścia z tej sytuacji trudnej nie tylko politycznie, ale i ekonomicznie. Aby utrzymać swą pozycję i zachować resztki samodzielności, hospodar musiał lawirować między sułtanem Sulejmanem, walczącymi ze sobą królami Węgier Ferdynandem I Habsburgiem i Janem Zápolyą oraz królem Polski Zygmuntem I Starym. Nadrzędnym jego celem stało się wzmocnienie państwa mołdawskiego poprzez uzyskanie nowych terytoriów: polskiego Pokucia i jak największych połaci Siedmiogrodu ${ }^{1}$. Pokucie było dla Mołdawii ważne ze względów gospodarczych, gdyż biegła tamtędy najważniejsza droga spędu mołdawskiego bydła w kierunku Śląska i Niemiec. Po utracie portów czarnomorskich był to jedyny liczący się kierunek sprzedaży tego najważniejszego mołdawskiego produktu, dlatego zdobycie tego trójkąta ziemi wdzierającego się w granice Mołdawii stało się głównym celem władców tego państwa już od czasów Stefana Wielkiego. Ustawicznie powtarzające się próby opanowania Pokucia przez Piotra Rareşa powodowały wieczny jego konflikt z królem Polski, z drugiej strony zarówno Polacy, jak i Mołdawianie zdawali sobie sprawę z niebezpieczeństwa eskalacji tego konfliktu, dlatego szukali też dróg porozumienia i nacisku na hospodara ${ }^{2}$. Zdobycze w Siedmiogrodzie były natomiast rezultatem sytuacji, jaka nastąpiła na ziemiach węgierskich w wyniku wojny domowej. Piotr Rareş przede wszystkim obawiał się Turków i niewątpliwie sympatyzował z Ferdynandem I Habsburgiem, jednak jako lennik sułtana musiał nie do końca szczerze współpracować z Janem Zápolyą, czego ten ostatni też nie mógł nie zauważyć. W tej skomplikowanej sytuacji Rareş notorycznie zmieniał sojuszników, wspierał raz jedną, raz drugą stronę konfliktu, próbując wyciągnąc $\mathrm{z}$ tego jak największe korzyści. Taka postawa budziła oczywiście spore kontrowersje wśród współczesnych mu władców, co znalazło swoje odbicie w postrzeganiu przez nich jego osoby. Celem niniejszej pracy będzie przeanalizowanie materiału źródłowego zawierającego opinie na temat hospodara, a pochodzącego z terenów spoza Mołdawii. Postaram się odpowiedzieć na pytanie: jak Piotr Rareş i rządzona przez niego Mołdawia były postrzegane przez osoby mu współczesne. Podstawę analizy stanowić będzie korespondencja Ferdynanda I Habsburga, króla polskiego Zygmunta Starego, sułtana Sulejmana Wspaniałego, a także Wenecjan: Ludovika Grittiego, Tranquilusa Andronika oraz Marino Sanuto. Punktem kluczowym mającym wpływ na ocenę Piotra Rareşa był jego atak na Pokucie na przełomie 1530 i 1531 roku, toteż większość przytoczonej przeze mnie korespondencji będzie dotyczyć okresu po tym wydarzeniu.

Pierwszą osobą, której stosunek do hospodara chciałabym omówić jest król Polski Zygmunt Stary. Zygmunt Stary był urodzonym dyplomatą, w odróżnieniu od swe-

${ }^{1}$ I. Czamańska, Between Poland and Ottoman Empire. The political and juridical status of Moldavia in the 15th-18th century, in: Turkey and Romania. A history of partnership and collaboration in the Balkans, Istanbul 2016, s. 187; idem, Poland and Turkey in the 1st half of the 16th century - turning points, in: Fight against the Turk in Central Europe in the first Half of the 16th Century, red. I. Zombori, Budapest 2004, s. 99.

2 I. Czamańska, Poland and Turkey, s. 99-100. 
go brata Jana Olbrachta nigdy nie podejmował decyzji pod wpływem emocji, także w korespondencji zachowywał swój dyplomatyczny ton. Jednak na podstawie jego listów kierowanych do Piotra Rareşa, jak i w listach adresowanych do innych osób, a poruszających temat hospodara, można dostrzec jaki był jego stosunek do władcy mołdawskiego. W celu omówienia jego stanowiska będę posiłkować się wybraną korespondencją króla polskiego, która daje wgląd w postrzeganie Rareşa na dworze polskim.

W uniwersale z 14 października 1530 roku kierowanym na sejmiki, Zygmunt Stary przestrzegał szlachtę, że dotrzymanie przez Rareşa zawartych traktatów jest wątpliwe, donosił, że hospodar dopuszcza się zuchwałych prowokacji, a całkiem niedawno zażądał w sposób bezwstydny, jak zostało to określone, wydania mu ziemi kołomyjskiej. Nadchodzący sejm powinien się więc zająć przygotowaniem również środków na odparcie ewentualnej napaści ze strony hospodara ${ }^{3}$.

Oczywiście jednym z głównych zarzewi konfliktów czy nieporozumień hospodara z Polską była sprawa Pokucia. Bardzo ciekawe są trzy kolejne listy z 1531 roku wymienione między Zygmuntem Starym a Piotrem Rareşem a dotyczące tej właśnie sprawy. Ukazują one dosyć szorstkie relacje panujące pomiędzy hospodarem a królem polskim. Otóż 3 lutego 1531 Zygmunt Stary odpowiadał na poselstwo Rareşa przybyłe na sejm piotrkowski ${ }^{4}$. Poseł mołdawski wyraził wówczas przekonanie, że na mocy darowizny królów węgierskich Pokucie należy się Mołdawii, że król polski bezprawnie zagarnął je po śmierci hospodara Bogdana, więc on [Rareş] odebrał je jako swoją własność i będzie jej bronił z całą potęgą turecką oraz posiłkami węgierskimi, wołoskimi i tatarskimi. Odpowiadając na to poselstwo Zygmunt Stary oskarżył Rareşa o złamanie przymierza, o to, że bez wypowiedzenia wojny najechał i zagarnął Pokucie, które legalnie należy do Polski. Na dowód zaś jego przynależności do Polski Zygmunt Stary powołał się na fakt, iż Stefan Wielki właśnie w Kołomyi, stolicy Pokucia, złożył hołd Kazimierzowi Jagiellończykowi. Ziemię tę zajął Bogdan Jednooki, tłumaczył dalej Zygmunt, ale została mu ona odebrana, tego może się Rareş dowiedzieć od najbliższych sobie ludzi, którzy to jeszcze pamiętają. Musi tylko popytać. Zygmunt Stary nie chce rozlewu krwi chrześcijańskiej i pragnie zachować pokój, jeśli tylko i Rareş go dotrzyma. Żąda zatem, by hospodar opuścił Pokucie, a szkody wyrządzone poddanym Królestwa wynagrodził. Bojarów prosił natomiast, by przekonali Rareşa do wypełnienia jego próśb, w przeciwnym razie będzie musiał z pomocą boską ukarać hospodara. Przestrzegał też Rareşa przed losem jego poprzedni-

3 Acta Tomiciana: epistolarum, legationum, responsorum, actionum et rerum gestarum, serenissimi principis Sigismundi primi, Regis Poloniae, magni ducis Lithuaniae per Stanislaum Górski canonicum Cracoviensem et Plocensem collectarum A.D. 1532, t. 12, wyd. S. Górski, Poznań 1906 [dalej: AT], nr 325; Archiwum Główne Akt Dawnych w Warszawie (AGAD), Metryka Koronna [dalej: MK] 45, $\mathrm{k} 480$.

4 E. Hurmuzaki, Documente privitoare la istoria românilor, supl. 2, t. 1, (1510-1600), nr 7, Bucureşti 1893 [dalej: E. Hurmuzaki]; zob. Biblioteka Czartoryskich, Teki Naruszewicza [dalej: TN] 46, k. 23. 
ka Bogdana ${ }^{5}$. Jednakże w liście tym kancelaria królewska nieopatrznie użyła zwrotu „Bohdanus, pater tuus” kierując te słowa do Rareşa, czego ten nie omieszkał wykorzystać.

W dniu 21 lutego tego samego roku, Rareş odpowiedział na list królewski ${ }^{6}$. Wytknął w nim, że tak jak błędnie kancelaria królewska nazwała go synem Bogdana, tak samo błędne są przekonania Polski, iż Pokucie należy do niej. Oznajmił, że nie boi się królewskich pogróżek, mało tego, groził interwencją turecką, węgierską, siedmiogrodzką i tatarską. Wypomniał ponadto Zygmuntowi, że ten odmówił mu zasiłku na haracz dla Turcji, chociaż sam się do tego zobowiązał. Protestował przeciw oskarżaniu go o wiarołomstwo, bo nie naruszył granic Polski, tylko zajął należącą do niego krainę. Poza tym słyszał, że w Polsce koronowany został nowy król, z którym on przymierza nie zawierał. Proponował też, by spór o Pokucie przekazać do rozwiązania Sulejmanowi Wspaniałemu i Janowi Zápolyi ${ }^{7}$.

Odpowiadając na te zarzuty (w liście z 31 marca 1531 roku), Zygmunt Stary z sarkazmem stwierdził, że skoro hospodar na swój sposób interpretuje listy królewskie pisane łaciną, to do tego listu załącza się również kopię ruską, żeby uniknąć nieporozumień. Ponadto wyjaśniał, iż nigdy nie zobowiązywał się do udzielenia mu zasiłków na haracz dla Turcji i pretensje hospodara są bezpodstawne. Koronacja młodego króla odbyła się z kolei na prośbę szlachty, tak, by mógł się on przygotować do pełnienia władzy. Dopóki jednak on żyje, jako stary król, wszelka władza pozostaje przy nim. Odrzuca też propozycję jakiegokolwiek arbitrażu w sprawie Pokucia, bo zawsze należało ono do Polski i nikt temu nie zaprzeczał. Bogdan próbował je zdobyć podstępem, ale został z niego wyrzucony i to samo spotka Rareşa. W liście tym nie ma już próśb o opuszczenie Pokucia, ponieważ wiedziano, że nie przyniosą one żadnych efektów, liczono się z tym, że wojna jest nieunikniona i oczekiwano jedynie na powrót posła polskiego z Konstantynopola - Jana Ocieskiego ${ }^{8}$.

Tymczasem 19 kwietnia 1531 roku Jan Ocieski donosił z Konstantynopola Krzysztofowi Szydłowieckiemu, że Rareş usilnie zabiegał u sułtana Sulejmana Wspaniałego i wielkiego wezyra Ibrahima Paszy o posiłki przeciw Polsce, lecz mu odmówiono. Jego zaś zapewniono, że zarówno sułtan jak i wielki wezyr chcą zachować przyjaźń z Zygmuntem Starym9 9

Opinia o Rareşu jako człowieku niegodnym zaufania wzrosła na dworze polskim po kampanii obertyńskiej. O knowaniach Rareşa przeciw Polsce informowała raz po raz kancelaria królewska. O niesłowności hospodara opowiadał podkanclerzemu koronnemu Piotrowi Tomickiemu 16 kwietnia 1532 roku biskup siedmiogrodzki Jan Statilius. Tłumaczył się on, że nie ponosi odpowiedzialności za to, co zro-

\footnotetext{
5 Ibidem.

6 E. Hurmuzaki, supl. 2, t. 1 (1510-1600), nr 8; zob. też TN 46, nr 15.

7 Ibidem.

8 AT 13, nr 90.

9 AT 13, nr 113.
} 
bił jego siostrzeniec Piotr Rareş. Wspominał, że podczas wizyty w Mołdawii, Rareş błagał go o zapośredniczenie przynajmniej zawieszenia broni z Polską. Z tego powodu Statilius wysłał do Polski swego prepozyta Franciszka w celu prowadzenia negocjacji pokojowych, jednakże w międzyczasie Rareş zmienił zadanie. Zdaniem biskupa, ktoś musiał nakłonić hospodara do zmiany stanowiska i odrzucenia rozejmu. Zaznaczył on, że być może dowie się kto to był przez swego posłańca, bawiącego u Rareşa na dworze ${ }^{10}$. Także Piotr Tomicki donosił królowi, opierając się na informacjach otrzymanych od Hieronima Łaskiego, o intrygach Rareşa przeciw Polsce ${ }^{11}$. Stanisław Lanckoroński 16 października 1532 roku zarzucał z kolei hospodarowi, że ten celowo próbuje nastawić sułtana przeciw Polsce przekazując mu fałszywe informacje jakoby hetman wielki koronny wraz z kilkoma tysiącami Polaków walczył po stronie Ferdynanda Habsburga przeciw Turcji. Co więcej, namawiał również Moskwę do walki z Polską ${ }^{12}$. Z kolei wracający z Turcji poseł polski Piotr Opaliński 13 marca 1533 roku skarżył się w liście do Zygmunta Starego, że już osiem tygodni temu opuścił Konstantynopol i dawno powinien już był dotrzeć do kraju, gdyby nie zasadzki zastawione przez hospodara mołdawskiego. Gdy był w drodze do Turcji, Rareş wysłał ze swych zamków siedmiogrodzkich kilkuset jeźdźców z poleceniem, by go zabili lub schwytali. W Konstantynopolu ostrzeżono go natomiast, że w drodze powrotnej napotka na jeszcze większe przeszkody. Ostrzeżenia te okazały się być prawdziwe, bowiem kiedy Opaliński wkroczył na Wołoszczyznę, tamtejszy hospodar Vlad pokazał mu tajne pisma Rareşa, w których ten domagał się, by Vlad zabił lub schwytał Opalińskiego $^{13}$.

Kolejnym przykładem na ograniczone zaufanie króla polskiego w stosunku do hospodara jest jego list z 20 września 1534 roku. Wówczas Zygmunt Stary przed swoim wyjazdem na Litwę ostrzegał możnych przed Piotrem Rareşem, podkreślając, że knuje on spiski przeciw Polsce i chce wyrządzić jej szkodę. Zygmunt Stary w swych listach, czy też instrukcjach kierowanych na sejm, wielokrotnie powtarzał, że nie wierzy on w słowa hospodara. Ten bowiem nie przestrzega żadnych umów, nie dotrzymuje słów i nie można na niego liczyć. Tak było chociażby 19 sierpnia 1538 roku w korespondencji z Ferdynandem I Habsburgiem, Zygmunt Stary żalił się na trud utrzymania dwóch armii, jednej do obrony przeciw Tatarom, drugiej przeciw Mołdawii. Na prośbę Ferdynanda, ażeby Polska nie atakowała Mołdawii, by ta mogła przyjść z pomocą Węgrom, Zygmunt Stary odpowiadał, iż nie wierzy w to, że Rareş nie trzymający się żadnych umów z taką pomocą pospieszy; nie można na niego liczyć, gdyż nie dotrzymuje danego słowa i nie może stanowić żadnej pomocy dla chrześcijan. Ale, jak odpowiadał, spełni prośbę Ferdynanda i poinstruował już Jana Tarnowskiego, by na

10 AT 14, nr 190 (rękopis: Biblioteka Czartoryskich w Krakowie [dalej: BCzar], rkps 271, s. 121122; TN 47, nr 93 [15 kwietnia]).

11 AT 14, nr 418 (rękopis: BCzar rkps 271, s. 338-340; TN 48, nr 41).

12 AT 14, nr 467 (rękopis: TN 48, nr 70).

13 AT 15, nr 142 (rękopis: BCzar rkps 271, s. 568-571; TN 49, nr 68). 
razie nie atakował Rareşa. Jeżeli ten obieca, że więcej nie uderzy na Polskę oraz naprawi wszystkie wyrządzone jej szkody, to wówczas Tarnowski wycofa swoje oddziały i pozwoli mu na wyprawę z pomocą Węgrom ${ }^{14}$.

Brak zaufania do Piotra Rareşa uwidocznił się też w momencie, gdy sam hospodar znalazł się w trudnej sytuacji. Po wyprawie Sulejmana na Mołdawię w 1538 roku uciekł on bowiem do Siedmiogrodu. Jan Zápolya, już wówczas szwagier króla polskiego, radził się swego teścia, jakie powinien podjąć działania, ponieważ sułtan domagał się wydania Piotra. Zygmunt Stary w liście do Jana Zápolyi z roku 1539, pisał, że znając naturę Rareşa, gdyby został on uwolniony na pewno od razu stworzyłby zagrożenie dla Polski i dla Węgier. Jeśli zaś zostanie zatrzymany przez Jana Zápolyę, wbrew woli Turcji, to wówczas sułtan może stać się jego wrogiem, który z zemsty spustoszy mu kraj, więc będzie musiał Zápolya wybrać mniejsze zło. Gdyby jednak obydwa wyjścia okazały się niedobre, wówczas trzeba będzie znaleźć trzecie i trzeba się tu kierować zasadą, że bezpieczeństwo ich własnych państw jest ważniejsze niż życie jednego człowieka ${ }^{15}$.

Zatem Zygmunt Stary zdecydowanie nie miał dobrego zdania o hospodarze, wielokrotnie podkreślał jego nielojalność i niewiarygodność, a przede wszystkim obawiał się jego działań. Ostrzegał przed jego dwulicowością i radził traktować jego zapewnienia z przymrużeniem oka i sporą dozą ostrożności.

W swych relacjach z Polską Piotr Rareş wielokrotnie straszył stojącym za nim sułtanem. Jednak opinia Sulejmana Wspaniałego na temat hospodara nie była wiele lepsza niż opinia króla polskiego. Sułtan, podobnie jak Zygmunt Stary, nie traktował hospodara jako człowieka godnego zaufania. Wręcz przeciwnie, jego niesubordynacja, nieustanne łamanie danego słowa czy układów, zmiana sojuszników sprawiało, że sułtan darzył go ogromną nieufnością. Przytoczę kilka przykładów.

W 1531 roku Jan Ocieski został wysłany do Porty, by poskarżyć się w imieniu Zygmunta Starego na to, że Piotr Rareş zajął niektóre pograniczne ziemie polskie, a kiedy król wysłał do niego posłów z zapytaniem o powód ataku, powiedział, że zrobił to na rozkaz sułtana. Dlatego Ocieski prosił sułtana o wyjaśnienie tej sprawy $^{16}$. Władca osmański zaprzeczył jednak twierdzeniom hospodara i stwierdził, że Rareş zrobił to samowolnie, a nie na jego polecenie. Toteż Sulejman Wspaniały wysłał hospodarowi list z rozkazem zwrócenia wszystkich zabranych ziem Polsce oraz nakazem nienaruszania więcej pokoju polsko-tureckiego. Co więcej, nawet będąc w konflikcie z Polską, Rareş nie powinien był wysyłać posła do Zygmunta Starego, ponieważ sułtan poinstruował go wcześniej, że nie powinien ani sam wysyłać posłów ani posłów przyjmować. W wypadku, gdyby ktoś miał jakiejś sprawy do hospo-

14 Documente privitoare la istoria Romaniei culese din arhivele polone. Secolul al XVI-lea, ed. I. Corfus, Bucureşti 1979, nr 6; Hurmuzaki t. 2, część 1, nr 127; oryginał w Haus-Hof-und Staatsarchiv, Wiedeń, Ungarica 36, kon. B, k. 114-115v.

15 Documente privitoare la istoria, nr 22 (31 grudnia; Kraków).

16 AT 13, nr 56, 112-113; I. Czamańska, Poland and Turkey, s. 100. 
dara powinien kierować je do niego samego jako zwierzchnika hospodara mołdawskiego ${ }^{17}$. W styczniu 1532 roku, w odpowiedzi na poselstwo Ocieskiego, Sulejman Wspaniały zapewniał króla polskiego, że jest wierny układom z Polską i w żadnym wypadku nie pozwolił Rareşowi napadać na ziemie Królestwa ${ }^{18}$.

Zatem również w oczach Sulejmana Rareş uchodził za człowieka niegodnego zaufania, co więcej szkodzącego interesom tureckim. Przede wszystkim takie obawy miał wobec relacji z królem polskim, z którym świeżo zawarł trwały układ pokojowy. Był to pierwszy tego rodzaju układ zawarty przez imperium osmańskie, niewątpliwie więc sułtan musiał być wówczas rzeczywiście zainteresowany zachowaniem dobrych stosunków z Polską. W liście z 21 grudnia 1533 roku Andrzej Tęczyński donosił z Konstantynopola Piotrowi Tomickiemu, że Ajas pasza i Ludovik Gritti oświadczyli, iż dla zapewnienia Polsce pokoju ze strony Mołdawii sułtan ma zamiar w stosownym czasie pozbawić Rareşa godności wojewody przy pomocy Węgier, Wołochów, Tatarów oraz Polski ${ }^{19}$. W tej sprawie porozumie się jeszcze z Zygmuntem Starym, na razie zaś życzy sobie, by Polska nie zaczepiała wojewody, a tylko odpierała ewentualne jego ataki. Co do następcy Rareşa sułtan porozumie się z królem polskim i wyznaczy takiego, który będzie mu odpowiadał. Słowa te potwierdził wielki wezyr Ibrahim Pasza w liście do króla polskiego Zygmunta Starego 3 marca 1534 roku ${ }^{20}$.

Oliwy do ognia w postrzeganiu Piotra Rareşa przez sułtana dodało niewątpliwie zamordowanie Ludovika Grittiego. Wenecjanin ten robiący oszałamiającą karierę na dworze tureckim, szybko wszedł do kręgu osób najbardziej zaufanych sułtana. Uczestniczył w wyprawie Sulejmana Wspaniałego na Węgry w roku 1529 zakończonej zdobyciem opanowanej przez Ferdynanda I Budy i oblężeniem Wiednia, a w 1534 roku został tam wysłany ponownie - tym razem sam- oficjalnie z misją utrwalenia wpływów tureckich w rządzonej przez Jana Zápolyę wschodniej części Węgier ${ }^{21}$. Prawdziwy cel działań Grittiego niewątpliwie jednak odbiegał od oficjalnego, do dzisiaj pozostaje kwestią sporną czy jego celem było przejęcie władzy w Siedmiogrodzie lub w Mołdawii, ograniczenie wpływów Jana Zápolyi, czy może osadzenie wiernego Turcji wojewody siedmiogrodzkiego ${ }^{22}$; faktem jest, że jego mi-

17 AGAD, Traktatowe Dokumenty Tureckie [dalej: AKW], dz.tur., k. 66, t. 29, nr 66 - kopia, oryginał nieznany; zob.: Matricularum Regni Poloniae summaria, excussis codocibus, qui in Chartophylacio Maximo Varsoviensi asservantur, contexuit indicesque adiecit Theodorus Wierzbowski. P. 4, Sigismundi I regis tempora complectens (1507-1548), t. 1 (Acta cancellariorum 1507-1548) [dalej: MRPS] IV/1, nr 5914, s. 346 (16-25 maja 1531; Konstantynopol).

18 AGAD, AKW, dz.tur., k. 66, t. 33, nr 75, zob. też: BCzar rkps 611, s. 109; regest: AT 14, nr 52 z niedokładną datą, zob. też: MRPS IV/1, nr 6144.

19 AT 15, nr 595.

20 AT 16/I, nr 147 (rękopis: TN 51, nr 144).

21 A. Decei, Aloisio Gritti în slujba sultanului Soliman Kanunî, după unele documente turceş ti inedite (1533-1534), w: „Studii şi materiale de istorie medie” 1970, t. 7, s. 101-161; T. Gemil, In faţa impactului otoman, w: Petru Rareș, red. L. Şimanschi, Bucureşti 1978, s. 147.

22 H. Kretschmayr, Ludovico Gritty. Eine Monographie, „Archiv für österreichische Geschichte“ 1896, t. 83, nr 1, s. 35; T. Gemil, In faţa impactului otoman, s. 148-150; idem, Romanii si otomanii in se- 
sja była zupełnie nie po myśli hospodara mołdawskiego, ani samego Jana Zápolyi ${ }^{23}$. Toteż uknuto spisek, za którym stał Piotr Rareş, Jan Zápolya i możni węgierscy, jego celem było zamordowanie Grittiego ${ }^{24}$.

Jednym z największych krytyków Piotra Rareşa, który miał najgorsze o nim zadanie był Tranquilius Andronik, sekretarz wspomnianego już Ludovika Grittiego: uważał go za prowodyra całego spisku zawiązanego przeciw Wenecjaninowi i obwiniał o jego śmierć. W przekonaniu Andronika Rareş miał się obawiać o swoją pozycję w Transylwanii (celem Rareşa było uzyskanie Siedmiogrodu, zaś misja Grittiego stanowiła zagrożenie dla jego planów) a także podejrzewał, iż celem Wenecjanina było również umocnienie pozycji tureckiej w samej Mołdawii ${ }^{25}$. $\mathrm{Z}$ tego powodu Rareş miał się chcieć pozbyć Grittiego. Toteż udawał początkowo przychylność dla Wenecjanina, zapewniał go o swej pomocy i wsparciu, a wszystko jedynie po to, by ten uspokojony faktem, iż w razie jakichkolwiek problemów może liczyć na pomoc hospodara, nie ściągnął wsparcia tureckiego. W rzeczywistości Rareş planował zabójstwo Wenecjanina. W tym celu podstępnie oskarżono Grittiego o to, iż wydał rozkaz zamordowania Emerika Czibaka - nowego wojewody siedmiogrodzkiego, i wykorzystano to jako pretekst do pojmania go. Oblężony w Mediaș przez wojsko mołdawskie i węgierskie Gritti zgodził się poddać, ponieważ otrzymał obietnicę hospodara mołdawskiego, że zarówno jemu, jak i jego synom nie stanie się żadna

colele XIV-XVI, Bucureşti 1991, s. 93; J.K. Schuller, Georg Reicherstorffer und seine Zeit. Ein Beitrag zur Geschichte von Siebenbürgen in den Jahren 1527-1536, Wien 1859, s. 50-52.

23 Urkunden und Aktenstücke zur Geschichte der Verhältnisse zwischen Österreich, Ungarn und der Pforte im XVI. und XVII. Jahrhundert: Aus Archiven und Bibliotheken: Gesandtschaft König Ferdinands I. an Sultan Suleiman I. 1534, Wien 1839, nr 37-39.

24 Kiedy Wenecjanin zmierzał do Siedmiogrodu, towarzyszył mu Hieronim Łaski, który zwrócił się do Grittiego z prośbą o pomoc w zdobyciu stanowiska wojewody siedmiogrodzkiego. Zaniepokojony tym faktem Zápolya chcąc uprzedzić działanie Wenecjanina, mianował wojewodą swojego poplecznika Emerika Czibaka. Jednak po przybyciu Wenecjanina do Siedmiogrodu możni węgierscy Dóczi i Batthyani doprowadzili do zaognienia relacji między Wenecjaninem a nowym wojewodą. Z inicjatywy Dócziego miało dojść do spotkania między zwaśnionymi stronami, lecz po drodze, w okolicach Felmer w nocy z 11 na 12 sierpnia 1534 roku Czibak został przez rycerzy Batthianiego zamordowany; F. della Valle, Breve narracione della grandezza, virtu, valore, et della infelice morte dell' Illmo Sigr Conte Alouise Gritti... (red. I. Nagy), Törtenelmi Tar 1857, t. 3, s. 38; A. Hirschberg, Hieronim Łaski, Lwów 1888, s. 211. W przekonaniu Constantinescu zabójcami Czibaka był nie Gritti tylko Dóczi i Batthyani. Autor powołuje się na relację sekretarza Grittiego Francesca della Valle, op. cit., s. 38. Całość była zaś uknutym przez Dócziego spiskiem, mającym na celu stworzyć pozory winy Grittiego i Łaskiego; zob. R. Constantinescu, Moldova şi Transilvania în vremea lui Petru Rareş. Relaţii politice şi militare (1527-1546), Bucureşti 1978, s. 73; Kretschmeyr z kolei jest zdania, że to nie Gritti zabił Czibaka, tylko najpewniej Batthyani, ale rozkaz musiał wyjść od Grittiego. F. Della Valle próbował zaś ukazać Grittiego w jak najlepszym świetle; zob.: H. Kretschmayr, op. cit., s. 74-75. Szerzej na ten temat: K. Niemczyk, Petru Rareș i Ludovicus Gritti. Historia trudnych relacji między hospodarem mołdawskim, a tureckim szpiegiem na Węgrzech, w: Silesia - Polonia-Europa: studia historyczne dedykowane Profesorowi Idziemu Panicowi, red. J. Sperka, Katowice 2019, s. 331-348.

25 AT 16/2, nr 644; więcej na temat relacji Ludovika Grittiego z Piotrem Rareşem: K. Niemczyk, op. cit., s. 331-348. 
krzywda. Oczywiście hospodar mołdawski słowa nie dotrzymał. Gritti został ścięty jeszcze w Siedmiogrodzie, a jego ciało poćwiartowane, zaś jego synowie przewiezieni do Suczawy. Tam Rareş wydał oficjalny rozkaz, by odwieźć ich z powrotem do Siedmiogrodu i wypuścić. Jednakże tajna klauzula mówiła o tym, że chłopcy mają zostać po drodze straceni ${ }^{26}$.

Wydarzenie to wywołało oczywiście oburzenie na dworze sułtana, na który dotarły wiadomości o pełnej winie władcy mołdawskiego za dokonanie tego mordu. Przekonywał o tym sułtana również Jan Zápolya, który natychmiast wysłał list do Sulejmana I zapewniając go, że za całym tym spiskiem stoją Piotr Rareş oraz István Maylath i János Dóczi - ludzie związani z obozem Ferdynanda I Habsburga ${ }^{27}$. Hospodar mołdawski czując, że grunt pali mu się pod nogami ${ }^{28}$, rozpoczął poszukiwania pomocy u Ferdynanda I proponując mu swą pomoc w walce z Turcją ${ }^{29}$, a 4 kwietnia 1535 roku deklarując mu lojalność i wierność ${ }^{30}$. Prosił go również o pośrednictwo w zawarciu pokoju z Polską. Ferdynand rzeczywiście wstawił się za Rareşem i wysłał posła do Zygmunta Starego z propozycją zawarcia pokoju polsko-mołdawskiego. Król Polski zareagował na niego z rezerwą: w liście z 6 marca 1536 roku, zaznaczył, że mimo szczerej chęci nie może zawrzeć rozejmu z Mołdawią z powodu starej wiarołomności hospodara, który nawet ostatnio po ustaleniu terminu rokowań na 26 marca urządził niespodziewany napad na ziemie polskie ${ }^{31}$.

Polityka hospodara, w szczególności jego deklaracja lojalności dla Ferdynanda Habsburga, były nie do przyjęcia dla sułtana. W marcu 1535 roku Maciej Łobocki relacjonował, iż usłyszał od swych przyjaciół, że sułtan zamierza wysłać wielkiego wezyra Ibrahima Paszę, by ukarać Siedmiogród i Mołdawię za zabicie Grittiego. Faktycznie, kiedy tylko Sulejman Wspaniały w styczniu 1536 roku wrócił z kampanii w Azji, postanowił działać. 4 kwietnia 1536 roku biskup Thurzo pisał do Ferdynanda Habsburga o decyzji Porty w sprawie pomszczenia śmierci Wenecjanina ${ }^{32}$. Żadnych działań jednak nie podjęto ani w tym, ani w następnym roku. Zmobilizowała sułtana dopiero kolejna interwencja dyplomatyczna króla polskiego, który w liście posłanym przez Erazma Trześciańskiego skarżył się na Piotra Rareşa i sugerował, że w interesie zarówno Polski jak i Turcji leży pojmanie hospodara. Sułtan przygotował już wówczas wyprawę do Mołdawii i w liście pisanym pod koniec lipca 1538 roku

26 F. della Valle, op. cit., s. 43 - 52; H. Kretschmayr, op. cit., s. 81-82; R. Constantinescu, op. cit., s. 73; A. Hirschberg, op. cit., s. 211.

27 R. Constantinescu, op. cit., s. 74.

28 Sułtan domyślał się, kto stał za zabójstwem Wenecjanina. Zdając sobie z tego najwyraźniej sprawę, 29 października 1534 r. Rareş prosił posła polskiego Lanckorońskiego o odnowienie przymierza z Polską, obawiając się ataku tureckiego (AT 16/2, nr 552).

29 AT 17, nr 25.

30 E. Hurmuzaki, t. 2, część 1, nr 66.

31 AT 18, nr 95 (rękopis: BJ rkps 6558, fol. 40v-41; BCzar rkps 258, s. 87-89; TN 54, nr 47).

32 E. Hurmuzaki t. 2, część 1, nr 76; zob: Haus-Hof- und Staatsarchiv, Wiedeń, Ungarica 28, konv D (April), k. 9-10. 
odpowiadał, iż chce spełnić życzenie króla Zygmunta złapania Rareşa i obiecywał zrobić wszystko, by ten plan został zrealizowany. Sułtan zalecał więc czujność na zamkach w Mołdawii i na Ukrainie, by tam Rareş nie znalazł schronienia oraz proponował uczulić na to hetmanów i wojewodów by odcięli drogę ucieczki uciekającym Mołdawianom $^{33}$. We wrześniu 1538 roku został z kolei wysłany z Turcji do Zygmunta Starego poseł Said bej (był to Jan Kierdej - wzięty w młodości do niewoli tureckiej, gdzie przyjął imię Said). Informował on króla polskiego, że sułtan dowiedział się, iż Rareş uciekł ze swojej ziemi i ukrywa się w Polsce, dlatego w imię przyjaźni polskotureckiej sułtan prosi, by Zygmunt Stary rozkazał go pochwycić i wydał go sułtanowi żywym albo umarłym. Był on bowiem wrogiem Turcji i ta musi go ukarać, by w przyszłości inni potencjalni buntownicy wiedzieli, że spotka ich taki sam los. Dlatego sułtan posyła z tym listem swego zaufanego człowieka ${ }^{34}$. Nie przyniosło to jednak żadnego rezultatu, ponieważ Piotra Rareşa na terenach Polski nie było.

Kolejna z postaci, której zdanie na temat hospodara mołdawskiego chciałabym przeanalizować jest osoba Ferdynanda Habsburga. Do roku 1535 hospodar traktował Ferdynanda Habsburga jako rywala, w szczególności, w kwestii Transylwanii. Toteż korespondencja Carneliusa Scheppera i Marcusa Pampflingera, a więc osób zaufanych Ferdynanda pełna jest wzmianek o poczynaniach Rareşa, na którego Habsburg patrzył dosyć nieufnie. Donosili oni Ferdynandowi o każdej plotce na temat poczynań hospodara i relacjonowali każdy jego krok, co świadczy o dosyć ograniczonym zaufaniu Habsburga dla hospodara. Ściślejsze relacje między Rareşem a Ferdynandem Habsburgiem zostały nawiązane w roku 1535, kiedy to po zabójstwie Grittiego, Rareş czuł się zagrożony zarówno przez Polskę, jak i Turcję. Toteż 4 kwietnia 1535 roku złożył Ferdynandowi Habsburgowi deklarację lojalności ${ }^{35}$. Jednak nawet wówczas zaufanie Ferdynanda do Rareşa nie było zbyt duże, bowiem 31 lipca 1536 roku Pamflinger i Banffy donosili Ferdynandowi o sytuacji w Transylwanii i o podwójnej grze Rareşa, której Habsburg był świadom ${ }^{36}$. Wprawdzie wstawił się jeszcze za hospodarem u Zygmunta Starego, kiedy ten zabiegał o rozejm z Polską, ale w momencie, gdy naprawdę potrzebował pomocy Habsburga, w roku 1538, Ferdynand w pierwszej kolejności kierował się interesem własnego kraju i pozostawił hospodara bez wsparcia.

Na koniec chciałabym jeszcze przedstawić opinię Marino Sanuto, weneckiego historyka i autora 58 tomów pamiętnika z lat 1496-1533. W tomie 56 zamieszczony został list Herculesa Daissoli sekretarza Hieronima Łaskiego do Paula Contarini'ego. Przesłał on sprawozdanie ze swych podróży dyplomatycznych odbytych w służ-

33 E. Hurmuzaki, supl. 2, t. 1 (1510-1600), nr 59 (rękopis: TN 56, nr 76: list Sulejmana do Zygmunta Starego z końca lipca 1538 informujący, że ten wyprawił się przeciw Rareşowi i prośbą, by Zygmunt go złapał, kiedy będzie szukał ucieczki); zob. też: I. Czamańska, Poland and Turkey, s. 101.

34 AGAD, AKW, dz.tur., k. 66, t. 57, nr 123.

35 E. Hurmuzaki t. 2, część 1, nr 66.

36 E. Hurmuzaki t. 2, część 1, nr 83; oryginał: Haus- Hof- und Staatsarchiv, Wiedeń, Ungarica 28, konv. F (Juli), k. 66-69. 
bie Jana Zápolyi z polecenia Hieronima Łaskiego od kwietnia 1531 roku, podając opis krajów, w których przebywał. Posłował do Ferdynanda Habsburga, do Budy i Siedmiogrodu oraz przebywał na dworze Piotra Rareşa. Podsumowując swą wizytę w Mołdawii stwierdził, iż kraj ten jest piękny i bogaty, lecz osoba władcy pozostawia wiele do życzenia (10 marca 1532) (17. $^{37}$.

Podsumowując należy stwierdzić, że obraz Piotra Rareşa w źródłach mu współczesnych wypada zdecydowanie niekorzystnie. W oczach większości władców postrzegany był jako człowiek niegodny zaufania, niesłowny, łamiący dane wcześniej obietnice. Zawierane z nim układy często nie były dotrzymywane. Jego niesłowność sprawiała, że zarówno w oczach króla Polski Zygmunta Starego, sułtana Sulejmana Wspaniałego, Ferdynanda Habsburga, a zatem najważniejszych jego partnerów politycznych, Piotr Rareş nie tylko nie cieszył się zaufaniem, ale sukcesywnie tracił wizerunek osoby, z którą można zawierać jakiekolwiek umowy polityczne. Prowadzić to musiało ostatecznie do utraty poparcia każdej ze stron i ostatecznej klęski hospodara.

Należy jednak wziąć też pod uwagę fakt, że oceny hospodara formułowane były w korespondencji dyplomatycznej, w której nie chodziło o szczerość, lecz o wywołanie pożądanego efektu, a konkretnie odstręczenie konkurenta lub przeciwnika od współpracy z Piotrem Rareşem, do której w gruncie rzeczy wszyscy dążyli.

\section{BIBLIOGRAFIA}

\section{Źródla archiwalne:}

Archiwum Gtówne Akt Dawnych w Warszawie (AGAD),

AKW (Traktatowe Dokumenty Tureckie), dz.tur., k. 66, t. 29, nr 66; k. 66, t. 33, nr 75; k. 66, t. 57, nr 123.

Metryka Koronna, 45, k 480.

Biblioteka Czartoryskich, Kraków,

rkps 271, s. 121-122; rkps 611, s. 109.

Teki Naruszewicza w 46, nr 15, 23; TN 47, nr 93; TN 48, nr 41; TN 48, nr 70; TN 49, nr 68; TN 51, nr 144; TN 54, nr 47; TN 56, nr 76.

Biblioteka Jagiellońska, Kraków, BJ rkps 6558, fol. 40v-41.

Haus-Hof- und Staatsarchiv, Wien,

Ungarica 28, konv D (April), k. 9-10; konv. F (Juli), k. 66-69;

Ungarica 36, konv. B, k. 114-115v.

\section{Źródla opublikowane:}

Acta Tomiciana: epistolarum, legationum, responsorum, actionum et rerum gestarum, serenissimi principis Sigismundi primi, Regis Poloniae, magni ducis Lithuaniae per Stanislaum Górski canonicum Cracoviensem et Plocensem collectarum A.D. 1532., wyd. S. Górski, t. 12-18.

Documente privitoare la istoria Romaniei culese din arhivele polone. Secolul al XVI-lea, red. I. Corfus, Bucureşti 1979.

37 AT 14, nr 126; zob. Sanuto Marino, I diarii Venezia 1901, t. 56, kol. 129-138. 
Francesco della Valle, Breve narracione della grandezza, virtu, valore, et della infelice morte dell' Illmo Sigr Conte Alouise Gritti... (red. I. Nagy), Törtenelmi Tar 1857, t. 3.

Hurmuzaki E., Documente privitoare la istoria românilor, supl. 2, t. 1, t. 2(1), Bucureşti 1891-1893.

Matricularum Regni Poloniae summaria, excussis codocibus, qui in Chartophylacio Maximo Varsoviensi asservantur, contexuit indicesque adiecit Theodorus Wierzbowski. P. 4, Sigismundi I regis tempora complectens (1507-1548), t. 1 (Acta cancellariorum 1507-1548).

Sanuto Marino, I diarii Venezia 1901, t. 56, kol. 129-138.

Urkunden und Aktenstücke zur Geschichte der Verhältnisse zwischen Österreich, Ungarn und der Pforte im XVI. und XVII. Jahrhundert: Aus Archiven und Bibliotheken: Gesandtschaft König Ferdinands I. an Sultan Suleiman I. 1534, Wien 1839.

\section{Opracowania i artykuly:}

Constantinescu R., Moldova şi Transilvania în vremea lui Petru Rareş. Relaţii politice şi militare (15271540), Bucureşti 1978.

Czamańska I., Between Poland and Ottoman Empire. The political and juridical status of Moldavia in the 15th-18th century, w: Turkey and Romania. A history of partnership and collaboration in the Balcans, Istanbul 2016, s. 181-192.

Czamańska I., Poland and Turkey in the 1st half of the 16th century - turning points, w: Fight against the Turk in Central Europe in the first half of the 16th Century, red. I. Zombori, Budapest 2004, s. 91102.

Decei A., Aloisio Gritti în slujba sultanului Soliman Kanunî, după unele documente turceş ti inedite (1533-1534), „Studii şi materiale de istorie medie” 1970, t. 7. s. 101-161.

Gemil T., În faţa impactului otoman, w: Petru Rareș, red. L. Simanschi, Bucureşti 1978, s. 136-150.

Gemil T., Romanii si otomanii in secolele XIV-XVI, Bucureşti 1991.

Hirschberg A., Hieronim Laski, Lwów 1888.

Kretschmayr H., Ludovico Gritty. Eine Monographie, w: „Archiv für österreichische Geschichte“ 1896, t. $83, \mathrm{nr} 1, \mathrm{~s} .1-107$.

Niemczyk K., Petru Rareș i Ludovik Gritti. Historia trudnych relacji między hospodarem mołdawskim, a tureckim szpiegiem na Węgrzech, w: Silesia - Polonia - Europa: studia historyczne dedykowane Profesorowi Idziemu Panicowi, red. J. Sperka, Katowice 2019, s. 331-348.

Schuller J.K., Georg Reicherstorffer und seine Zeit. Ein Beitrag zur Geschichte von Siebenbürgen in den Jahren 1527-1536, Wien 1859. 